\title{
The Application of Sundanese Vernacular Concept to The Design of Modern Building - Case Study: Aula Barat (West Hall) of Bandung Institute of Technology, West Java, Indonesia
}

\author{
Purnama Salura ${ }^{1}$, Stephanie Clarissa ${ }^{2}$, Reginaldo Christophori Lake ${ }^{3}$ \\ ${ }^{1}$ Universitas Katolik Parahyangan, Bandung, Indonesia \\ ${ }^{2}$ Cetta Gantari Indonesia Research Centre, Indonesia \\ ${ }^{3}$ Universitas Katolik Widya Mandira, Kupang, Indonesia \\ 1*purnamasalura.ps@unpar.ac.id, cettagantariindonesia@gmail.com,reginaldo@unwira.ac.id
}

Received: $27^{\text {th }}$ February $2020 \quad$ Final version received: $20^{\text {th }}$ April 2020

\begin{abstract}
As a reaction to the monotonous expression of typical International Style architecture, vernacular architecture is often applied to the design of modern buildings. Unfortunately, most of these applications are limited to copy existing vernacular architectural elements. This research aims to elucidate the application of Sundanese vernacular concepts in modern building designs. In line with this purpose, the Aula Barat (West Hall) Bandung Institute of Technology designed by Maclaine Pont was chosen as the case study. The analysis showed that the Sundanese vernacular concept was presented through the shape of the roof, which is similar to the vernacular house and mosque in the Sundanese village; while the modern lamella construction provides a wide-span structural system. This research complement existing research about Sundanese vernacular architecture, by exploring in-depth how to designed modern buildings that fit new functions and to its zeitgeist, but at the same time embodied the local expressions. It is expected that in the future modern buildings are no longer designed in the form of frozen vernacular architecture. The results of this research can also be a valuable input for stakeholders and architectural conservationists, as well as a source of knowledge for the laypeople.
\end{abstract}

Keywords: Application, Architecture, Modern Building, Sundanese, Vernacular

\section{INTRODUCTION}

It was said that human civilization undergoes three important revolutions that shape the course of history, namely the cognitive revolution, the agrarian revolution, and the scientific revolution which is characterized by technological advances (Harari, 2014). One result of this technology advancement is globalization, which seen as the process of international integration that occurs due to the exchange of world views, thoughts, and other cultural aspects (Rodrik, 2011; Falk, 2016; Michie, 2017). As an artifact of culture, architectural designs also influenced by the phenomenon of globalization. Especially in developing countries like Indonesia, various forms of vernacular architecture are now replaced by the skyscrapers that tend to uniformly mimic the shapes of buildings in developed countries (Eldemery, 2009; Salim, 2011).
In the field of architectural practice, this uniformity and monotonous architectural expression concerned the majority of designers (Rashid, 2015). As a reaction to this phenomenon, there seems to be a lot of movements that longing to return to the forms of Indonesian vernacular architecture. This is indicated by the many modern building design contests that put forward the notion of "back to local wisdom" or "vernacular architecture" as one of the design criteria (Allahham, 2014; Sholihah, Agustiananda, Junanah, \& Setiawan, 2019). Unfortunately, research on the performance of the contest winners actually shows that the concept of vernacular architecture has not been applied correctly, but just as mere rhetoric (Salura \& Fauzy, 2013). 
Some naive efforts for adopting the forms of vernacular architecture without an in-depth understanding will lead to a "frozen" vernacular architecture, which in fact degrades the value of vernacular architecture itself (Lefaivre \& Tzonis, 2011; Rouhi, 2016; \& Eickhoff, 2020). Moreover, as a contest winner, this kind of buildings will certainly be a reference for designing other buildings. This condition is exacerbated by the scarcity of academic publications regarding the suitability of the application of vernacular concepts in the design of modern buildings, which are carried out based on objective research and are based on reliable literature (Arbi, 2017; Malik \& Hassan, 2019).

Departing from this phenomenon, this research aims to elucidate the application of Sundanese vernacular architectural concepts to the design of a modern building. In addition to being able to explicate the suitability of the building's architectural expression to its nature and local cultural traditions, this research also explored how the building can accommodate new types of function.

This research contributed to the development of architectural theoretical as well as practical knowledge. It complements previous research on the concepts of Sundanese vernacular architecture, by discussing in depth the application of Sundanese vernacular concepts in modern buildings that accommodate public functions. For architectural practitioners, these examples of applications can be a source of inspiration for designers who intend to integrate local elements with modern technology. This research is also useful for stakeholders in the field of architectural conservation, by providing specific input on important aspects of a building that can be used as guidelines in conservation movements. As for the general public and laypeople, this research can be a source of knowledge in appreciating architectural works.

\section{MATERIALS AND METHODS}

\subsection{Case Study}

The efforts to integrate vernacular architecture with modern building design is very often done. In fact, the adoption of architectural forms from developed countries did not just happen in the 20th century but had already begun at the beginning of the 19th century, in the period of Dutch colonialism (Kurniawan \& Kusumawardhani, 2012). At that time, most
Dutch architects tended to "import" European architectural style, by applying the style to the design of public buildings in Indonesia. Ironically, the building with European style is considered as a progress, because it was seen as an association of styles that are considered as modern (Kusno, 2000).

One of the Dutch architects who opposed this opinion was Henri Maclaine Pont (Sumalyo, 1993). He argues that the climate and culture of Indonesia are very different from the climate and culture of European countries, so ideally it is responded differently by the architecture. Therefore, he insisted that building in Indonesia should not merely be a mere tropic version of Dutch architecture. Pont's works were later given the term Indische Architecture; architectural works that were considered successful in synergizing local aspects with the knowledge of modern construction (Soekiman \& Purwanto, 2018). In accordance to the historical records, The Indische-architecture movement began in Bandung and then spread to other cities. At that time, the city of Bandung in West Java became a center of excellence in the field of architecture, because the city was prepared to be the capital of the Dutch East Indies (Passchier, 2007). Therefore, the city of Bandung was chosen as the research location. The native people of Bandung, as well as other West Java area, is called the Sundanese people (Rosidi, 2018).

Previous research shows that one of Pont's works in Bandung, which until now remains in a good condition, become an icon that represents Sundanese architecture, has a deep meaning for the community, even classified as one of the cultural heritage, is the West Hall of the Bandung Institute of Technology (ITB) (Suratman, 2012; Suryono, 2015). Since its establishment in 1920 until now, the building houses seminars, exhibitions or meetings. It can be said that this building is a modern building that accommodates public functions. Although the design is considered successful, it is necessary to further explore the building's elements and configurations which tend to be interpreted as a building that expresses local Sundanese characters. Thus, in the future, it was hoped that architectural practitioners could learn from the design of this building to create a new and better architectural work, not just imitating the building's elements. Based on these considerations, the West Hall building was chosen as a case study. The following picture 
shows the location of the building, as well as the re-drawing of the floor plan, elevations, and sections of the building.
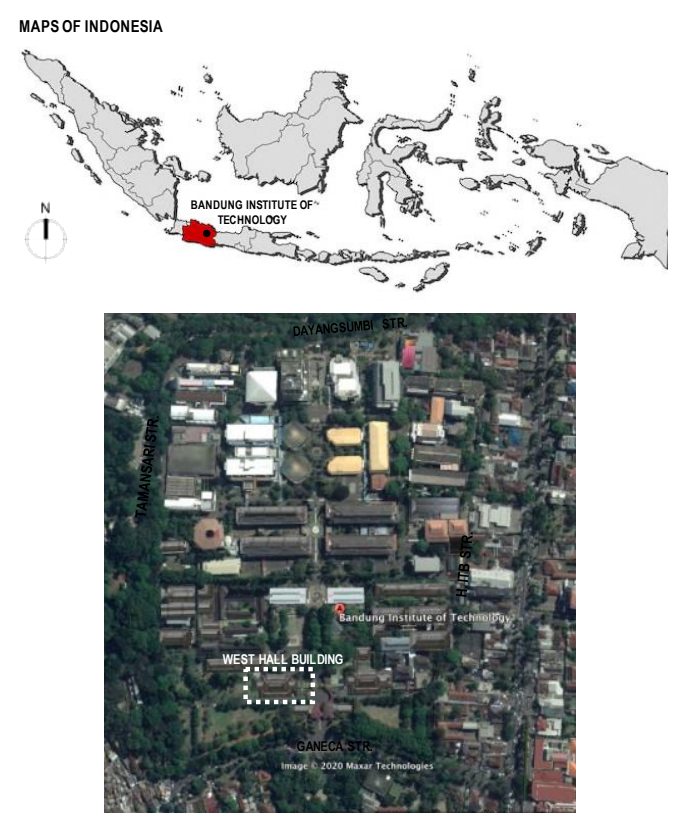

Figure 1: The location of West Hall of Bandung Institute of Technology

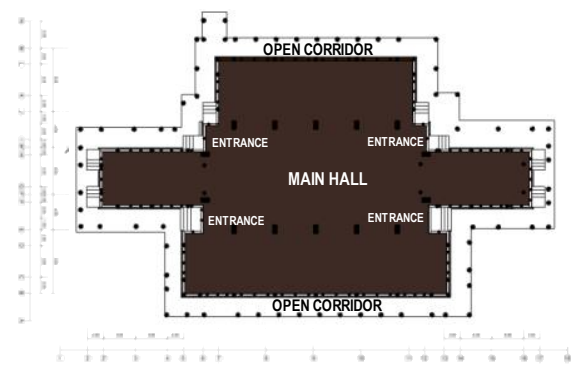

Figure 2: Floorplan

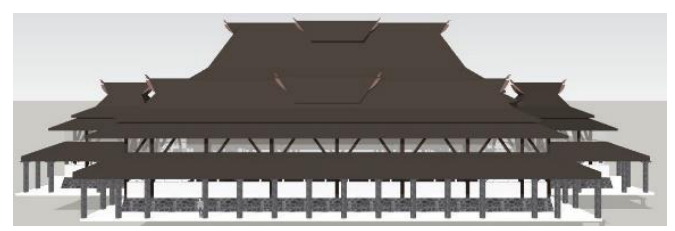

Figure 2: South elevation

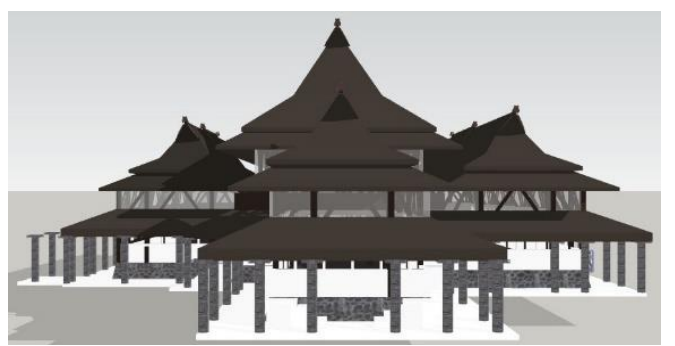

Figure 3: East elevation

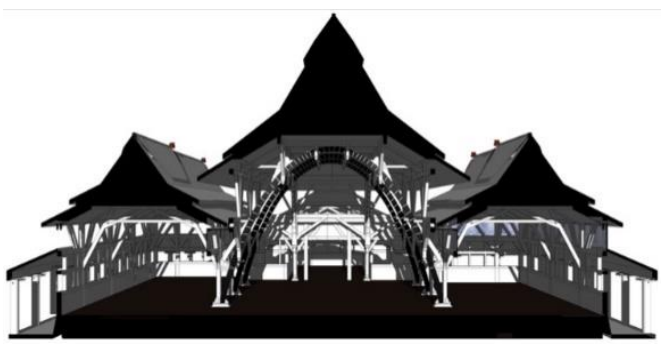

Figure 4: Section

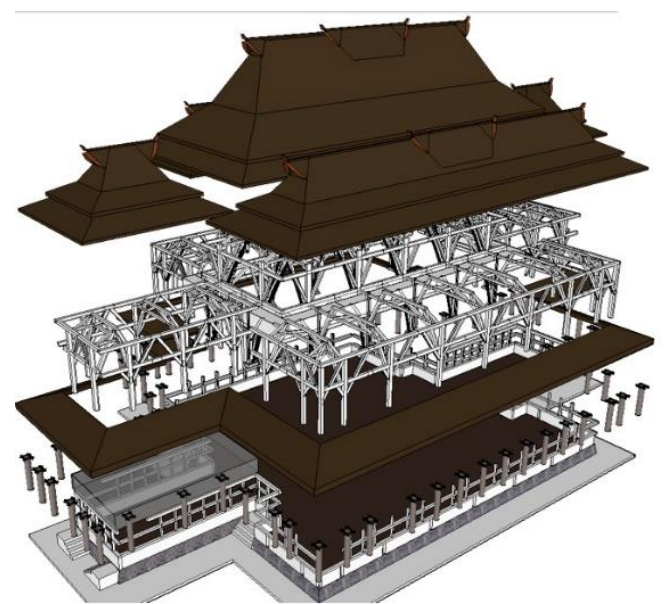

Figure 5: Axonometric drawing

\subsection{Analytical methods}

It was believed that the expression of architectural forms is always going to be interpreted by its users and observers (Salura, 2013; Askari \& Soltani, 2018). The building's users always interpret the suitability between the building's architectural expression and the functions (activities) that take place in it, by comparing it to other different functions. It is also believed that the vocabulary of knowledge in the minds of observers about other architectural expressions in a place that has a different nature and culture, shall greatly affect the interpretation process (Salura, 2018a).

This understanding raises two important aspects to be studied, namely the aspects of function and the expression of architectural form. The West Hall was designed to accommodate a new type of function, which is the multi-purpose hall within the campus complex. In the past, this function was never found in the Sundanese villages around West Java. On the other hand, the expression of its architectural form is expected to reflect the local character of the Sundanese architecture. Thus, the treatment of these two aspects shall certainly be resulting in different architectural expressions. 
This research discusses how to interpret the expression of functions and architectural forms by describing the two aspects through the universal principle underlying the creation of each architectural work, namely the principle of identification of the architectural property and the principle of orientation-hierarchy in composition (Salura, 2018b). For example, because it functions as a multipurpose building inside a university complex, this building requires formal expression. The principles that can provide formal expressions are symmetrical composition, the clarity of axis, as well as having a clear hierarchy and orientation (Salura \& Clarissa, 2018). Meanwhile, as a public building, it needs to manifest an inviting expression to the public. Thus, the composition of the building inside the university complex should be designed to create a continuous flowing movement from the outside to the inside of the building, as well as having the position of an entrance that is clear and easily identified. The interior-space should be designed to be used flexibly; while the outer architectural forms express lightness instead of bulky, more transparent instead of massive, and blending with the surrounding environment.

Hitherto, research on Sundanese culture, especially about its architecture, is very rarely done. The studies on Sundanese architecture are usually focusing on the typology of building elements; studies like this generally emphasize the distinctive shape of the Sundanese roof. The latest research on Sundanese architecture found that the concept of sineger tengah and kaca-kaca is underlying its architectural forms (Salura, 2018c). Unfortunately, by the time Pont design the West Hall building, this research was not yet done. Thus, it was seen as pointless to trace these two concepts in Pont's design. The interpretation of local Sundanese characters in this study will be conducted based on building's attitude towards its natural and cultural context. The more the building elements correspond to the natural conditions, the more it shall be interpreted as local. Likewise, the more the building elements act as an icon to the local cultural context, it shall be interpreted as having a high local value (Chandra, 2012). Based on this analysis, it can be determined whether the expression of the building has a high local value as well as being able to accommodate its function properly, or vice versa.

Based on the literature review, the analysis steps are determined as follows:
Firstly, describing the property and composition of the building's architectural expression. The building would be observed from afar, as observed from its surrounding environment; from inside the site; near the building's entrance; until to the interior of the building, i.e. on the shape of the building itself, its structural-constructional system, as well as the configuration of its inner space. A detailed description of architectural composition and property is important because, through this description, it can be seen which part of the building that dominates the whole composition.

Secondly, integrating the research with questionnaires, to study the perception and interpretation of users and observers. It is realized that the opinions of users and observers who come from the laypeople sometimes failed to notice by architects and academic experts (Bonta, 1979; Shahedi, 2012). This is unfortunate, considering that this input is certainly useful for architects in the design process. Likewise, the questionnaire method was conducted so that the results of the research were not based on the interpretation of the researchers themselves, but also based on the interpretations of observers and users. Thus, it is hoped that research objectivity shall be maintained. The respondent came from building users, observers, and architectural experts. Respondents of this research amounted to 45 people in total, with each group consisted of 15 respondents.

Thirdly, interpreting the part of the building that expresses the Sundanese and modern concept. Thus, based on this in-depth explication, it can be analyzed the building elements or composition that dominates the view. It could also be traced whether this dominant part tends to reflect the Sundanese or even modern concept.

\section{RESULT AND DISCUSSION}

\subsection{Description of architectural property and composition of the West Hall}

The building's architectural expression as observed from its surrounding environment

The complex of the ITB Campus is located in the Dago area. The site is positioned in axis with Mount Tangkuban Perahu at the north, and Ganesha Park which is located at the south of the campus. The complex is bounded by 4 roads: Ganeca str. to the south, Tamasari str. to the 
west, IR.H. Juanda str. in the east, and Dayang Sumbi str. in the north, with the main entrance access on the Ganeca str. (Figure 1). The campus complex is surrounded by a pedestrian area. On both sides of the entrance, there is a specific entrance for pedestrians. This entrance area is directly connected to the open-corridor, straight to the West Hall area.

The West and East Hall (which is identical to the West Hall) is positioned precisely behind the entrance on Ganeca Str. Even though it is closest to the road, lush vegetation around the campus area causes the building to be hidden from the outside. Observed from the entrance on the Ganeca str., the building element that vaguely visible is the tip and top of the roof. From this part of the roof alone, it almost impossible to describe its properties and composition.

\section{The building's architectural expression as observed from its site}

The composition of buildings inside the site was arranged in an orderly grid. In the site, the West Hall is the closest to the entrance area of the ITB complex and is positioned facing the East Hall. Both of these buildings seemed to be a gate to enter the campus area. Its outermost position and closest to the road embodied its function as a public building. In between these two buildings, there is an open space in the form of a plaza that acts as the center of orientation. The presence of the plaza helps to guide visitors in identifying surrounding buildings inside the campus complex. Besides, the presence of this relatively spacious plaza allows the West Hall to be seen as a whole.

Observed from the plaza area, it appears that the building consists of more than one mass, positioned in a different elevation and similar roof shape (Figure 7). Although similar, at this distance it appears that the mass at the back has a higher hierarchy because of its greater proportions. Seen as a whole, the most dominant element of the building is the roof elements that seem to be gradual in elevation. The roof made of brown shingle material that has been used as roofing material in local community houses. Further identification shows that the shape of the roof looks similar to the ones found at Garut and Tasikmalaya villages in the 1900s (Dyck, 1922). Around the building, there is an open corridor (selasar) that connects the West Hall with other buildings that function as lecture buildings. Its roof is supported by round columns made from stone material. This open-corridor surrounding the entire building gives the impression of lightness and inviting, as well as indicates that this building was adapting to the tropical climate.

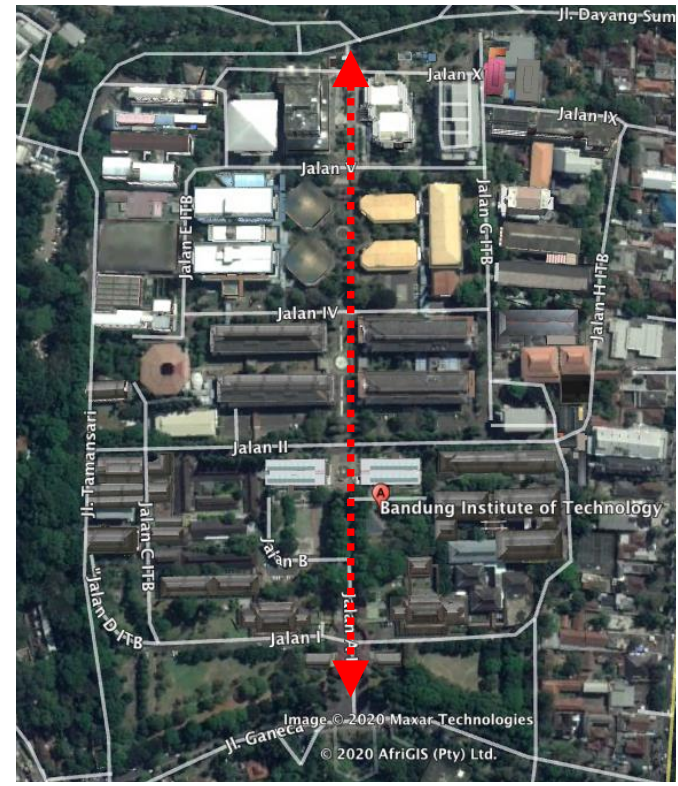

(a)

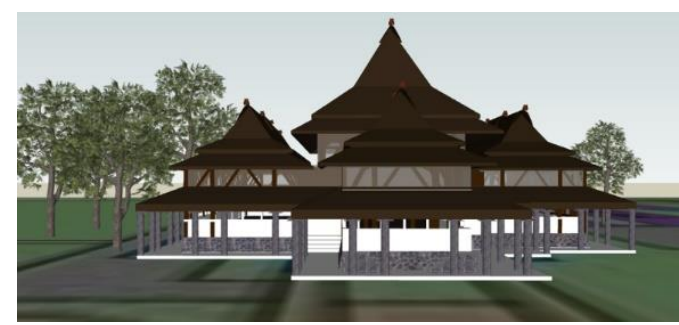

(b)

Figure 6: Site axis and the grid organization of the site (a) and the West Hall as observed from the plaza area (b)

The building's architectural expression as observed from near the entrance and inside the building

Observed near the main entrance, the composition of river stones at the bottom of the building dominates the view; while the appearance of a sequence of round stone columns dominates the side view. All of these building elements use the material commonly found in Sundanese villages. However, the shape of a round column is never found throughout the vernacular architecture in the Sundanese village. Thus, it can be concluded that the existing form refers to modern construction techniques. Nevertheless, the overall expression of the building is still dominated by the stone material, 
which is similar to the vernacular architecture in the Sundanese villages.
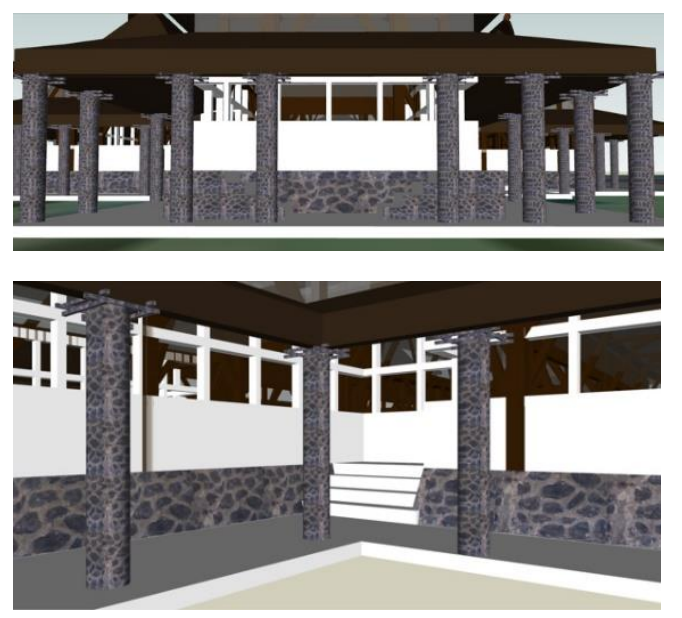

Figure 7: The West Hall as observed near the building entrance

Observations of the spatial layout show that the building is composed of 4 rectangles, with 1 largest rectangle, positioned in the middle (Figure 9). The building masses are symmetrical in composition. The re-drawing of the building also showed that all of the rectangle-shape masses was covered by a similar roof shape. However, the roof in the middle of the building is larger and positioned at a higher elevation than the other four roofs. Thus, the mass in the middle conveyed a message that it has a higher hierarchy compared to masses on all four sides. This building has 4 main entrances in the northsouth part of the building, which directly leads to the circulation of the main hall. Following the rectangular mass, the interior space is also rectangular in shape. The spatial layout inside the West Hall seems to be divided into 5 parts. But actually, the five spaces are not permanently delineated, so the spaces can be flexibly combined. Each space is connected by a simple and effective linear circulation path.

Based on the results of re-drawing (Figure 6 ), it can be seen that each element of this building has an ordered rhythm. There are repetitions of the use of material, colour, to the dimensions of building elements. For example, each unit has the same building material, which is natural wood and stone, and brick as a spatial enclosure. The colour of these natural materials reminds the observer of the expression of the original houses in Sundanese villages. In addition, each building elements have different sizes but has the same proportion. This applies even to the size of the building roof truss structure.

Observed inside the building, it was seen that the building uses wooden-lamella construction. This construction has never been found in the Sundanese villages, or even in another village in West Java area. The expression of the roof construction material on the inside is made of curved wood and the details resembling wooden buildings in America and Europe in the 1900s. This construction succeeded in creating a wide span of space, without being interrupted by columns.

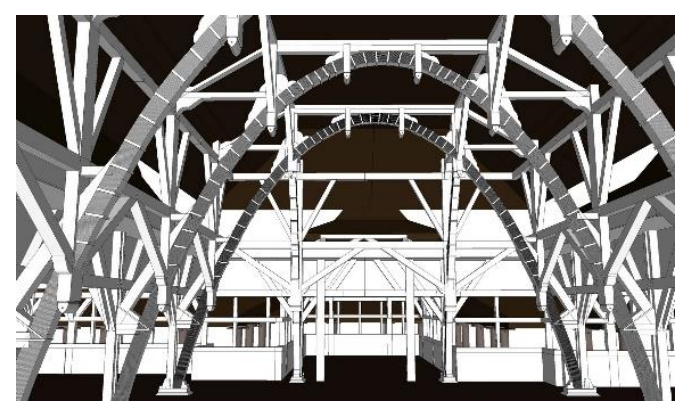

(a)

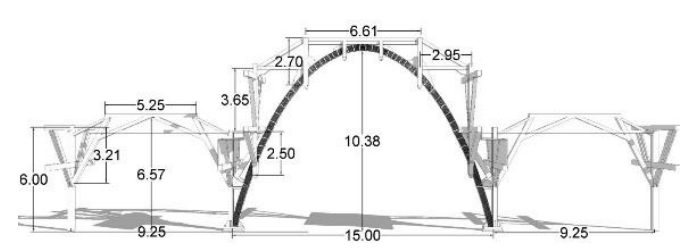

(b)

Figure 8: The West Hall as observed inside the building (a) and the dimension of structural system (b)

Based on the description, it can be seen that the dominant building element seen from afar is the roofs. Near the building entrance, it was seen that the spatial enclosures use local materials that resemble the materials used in the Sundanese villages of West Java. Whereas inside the building, the most dominating element is the modern lamella structure adopted from American and European buildings. 


\subsection{The questionnaires}

The results of the questionnaires can be seen in Figure 10. The questionnaires divided into 3 parts; the first part of the questions focused on the perception of observers on which part of the building elements are dominant, which is observed from the plaza, as well as at the entrance of the building until entering the inner space of the building.

The second part focuses on whether the most dominant element of the West Hall tend to remind observers of Sundanese vernacular building elements, or are similar to building elements that come from different countries, especially the developed ones.

The third part focuses on the ability of the building's architectural expression to conveyed a message that it is accommodating public functions. Firstly, focuses on the outer and inner architectural expression of the West Hall building. The respondents were asked whether its expression tends to be inviting or closed. Secondly, whether the location of the entrance and the position of the spaces inside the building are easy to identify.

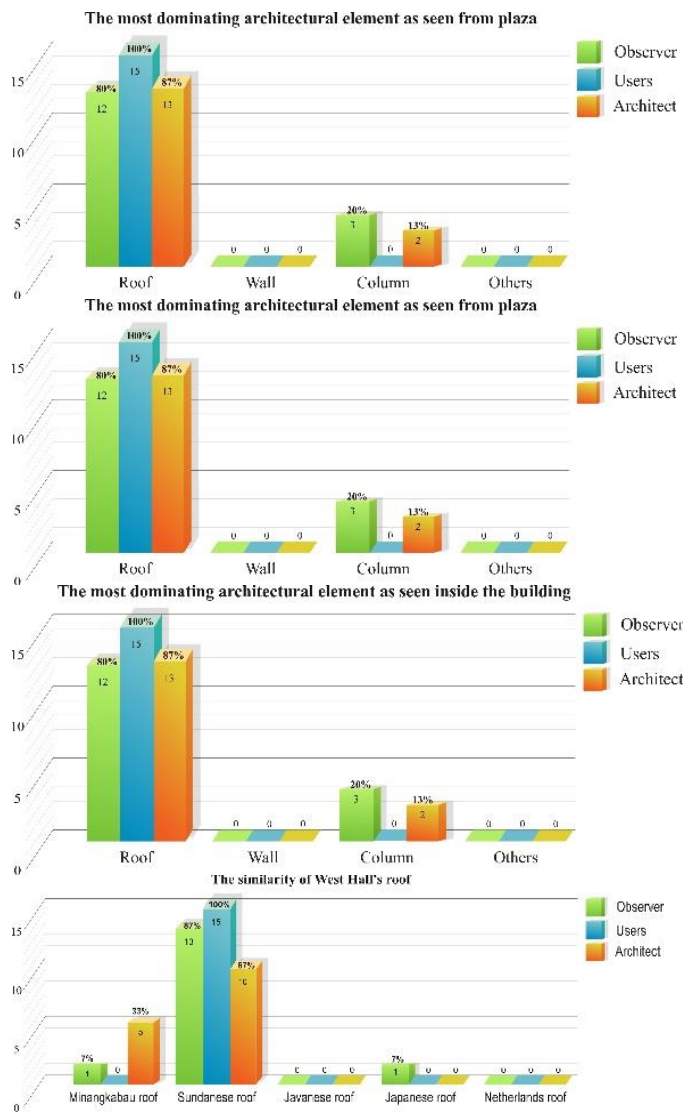

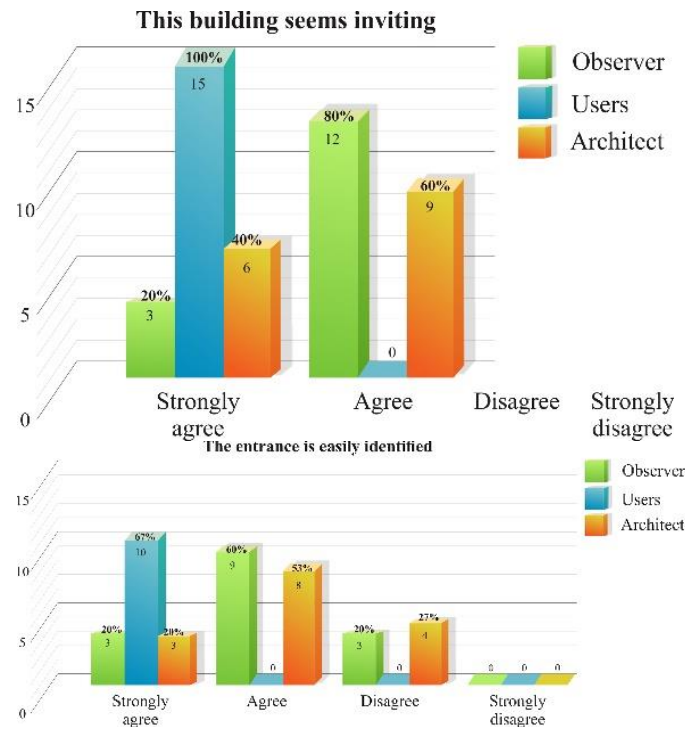

Figure 9: Results of the questionnaires

\subsection{Interpretation of the application of Sundanese vernacular architecture to the architectural design of West Hall building}

During his lifetime, Pont wrote quite a several works that covered his thinking about architecture, both published and unpublished (Mahatmanto, 2001; 2002). Unfortunately, his writing about the architecture of the West Hall is only a few lines in his personal letter, as well as a brief description to provide an explanation to the assignor. Therefore, there are many opinions concerning his architectural design. One of the most frequent issues among the architects was the remark of Pont's colleague, C.P. Wolf Schoemaker: "Why is the roof of the West Hall (which was built on the island of Java), actually used the Minangkabau roof?" (Jessup, 1975).

Based on the re-drawing of the building, it could be seen that the roof is in the shape of the hip roof, the combination of simple Sundanese roof construction with lamella construction. When observed in detail, it was seen that this roof is composed of three layers. The composition of the lowest and middle layers is similar to the roof of bale nyungcung, which is a mosque building in the Garut area, West Java. The difference is that the roof of the mosque is centralized, while the roof of the West Hall is elongated; although it is still in the category of the stepped roof type. The upper layer with a slightly protruding tip was inspired by the julang ngapak, which is the roof of vernacular houses in the Sundanese villages. The edges of the roof are 
made pointed, with fins on the back of the roof as a place of air exchange. On the roof, there are openings in the shape of fins, which look like gills on fish, and windows that look like windows in European houses. The placement of the fins and windows is an effort of Pont's adjustment to the building's need for light, as well as natural ventilation. It can be concluded that the shape of the West Hall's roof shows a combination of the bale-nyungcung roof and the julang ngapak, both of which are typical West Java roof shapes, with the typical jalousie founds in buildings in the Netherlands, for practical purposes. In contrast to the hip roof in the West Hall, the roof of the Minangkabau house is a gable roof with the truss angled at the edges. With these differences in character, it is clear that the roof of the West Hall did not adopt the Minangkabau roof.

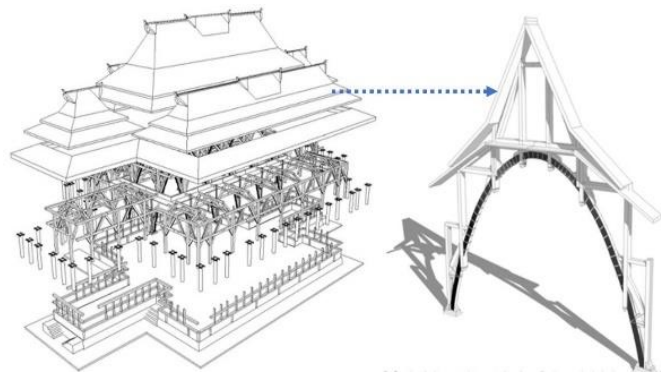

(a)

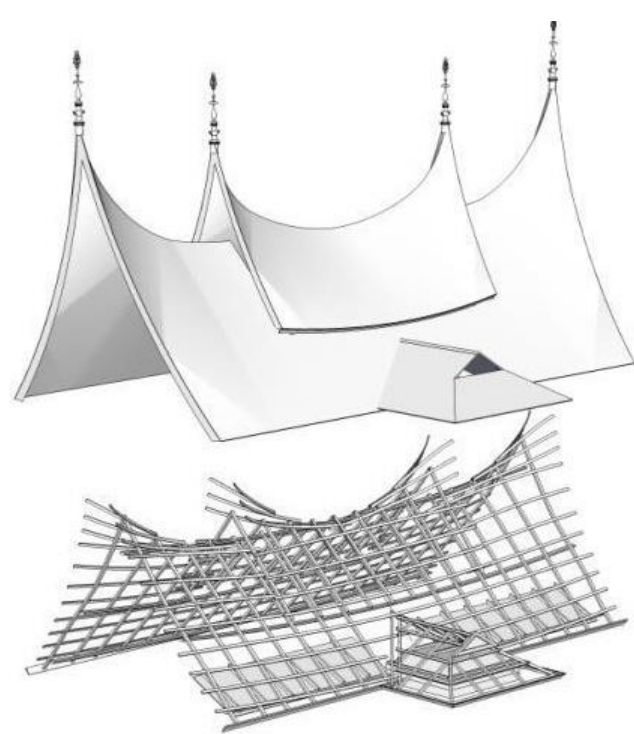

(b)

Figure 10: The differences between the constructional system of Wes Hall roof (a) and Minangkabau roof (b)
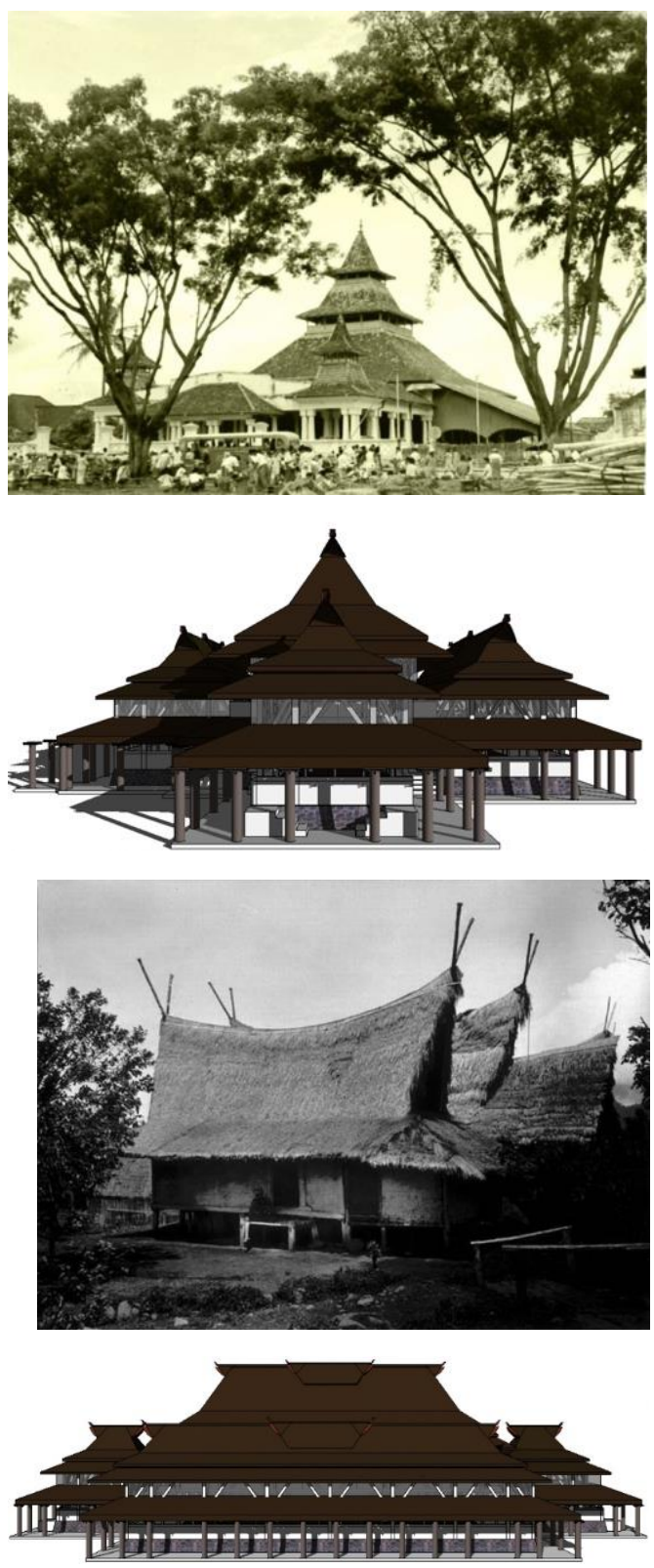

Figure 11: The resemblance between the bale nyungcung and julang ngapak roof with the roof of West Hall

The combination of Sundanese and modern concept is also applied to the overall site configuration and the composition of building mass. In accordance with campus functions that tend to be modern, the composition of buildings in the site was arranged in an orderly grid, instead of organically arranged. This arrangement tends to express a formal and modern expression. The formal expression was also created from the presence of plaza and continued path as an axis, that divide the site into two symmetrical part. However, the 
composition of the West Hall roofs itself, was similar to the shape of the composition of houses in Sundanese villages. The open-corridor that surrounds the building, while also connecting with other buildings, shows that the building is responsive to the local climate. With the sequence of columns, these additive elements conveyed a lighter effect as it rises upwards, resulting in an overall impression that this building is more integrated with its surroundings. In addition to showing local Sundanese architectural expressions, this lightness expressed openness to the public, which is very suitable for public buildings.

Compliance with the demands of the multipurpose hall is shown through the use of a widespan lamella construction that allows the continuous and flexible spatial layout, without distracted by structural columns. Unfortunately, this composition cannot clearly show the entrances of the building. This happens because Pont does not provide an accent that distinguishes or shows the position of the entrances of the building; it seems that the entrances are hidden. There are only stairs at each door to indicate that those are the pathway to enter or leave the building. For first-time visitors, the entrance to the building is very difficult to identify. Whereas as a public building, a clear and easily identifiable entrance position is needed.

Overall, it can be concluded that the application of Sundanese architectural concepts in the West Hall is realized through the use of typical Sundanese roofs, especially the combination of the form of the bale nyungcung roof with the julang ngapak roof. The bale nyungcung building is the only building with public functions found in the local (native) architecture of West Java. This form is used as a reference because it accommodates public functions, which is the same as the West Hall building. Meanwhile, to fulfill its demands as a wide-span building, the construction system used is a modern construction, which is the lamella construction, made with local materials. This constructional element itself already shows an exemplary combination of modern technology and local appearance from the materials used.

Table 1: The Sundanese vernacular and modern architecture concept in the design of West Hall building

\begin{tabular}{|c|c|c|c|}
\hline \multirow{2}{*}{\multicolumn{2}{|c|}{ Scope of analysis }} & \multicolumn{2}{|c|}{ Underlying concept } \\
\hline & & \multirow{2}{*}{$\begin{array}{c}\text { Sundanese } \\
\text { vernacular } \\
\text { architecture } \\
-\end{array}$} & \multirow{2}{*}{$\begin{array}{c}\begin{array}{c}\text { Modern } \\
\text { architecture }\end{array} \\
-\end{array}$} \\
\hline $\begin{array}{l}\text { The building's } \\
\text { architectural expression as } \\
\text { observed from its } \\
\text { surrounding environment }\end{array}$ & $\begin{array}{l}\text { The shape of upper part of } \\
\text { building's roof }\end{array}$ & & \\
\hline \multirow{3}{*}{$\begin{array}{l}\text { The building's } \\
\text { architectural expression as } \\
\text { observed from its site }\end{array}$} & $\begin{array}{l}\text { Composition of the building as a } \\
\text { whole }\end{array}$ & $\sqrt{ }$ & \\
\hline & Properties of its elements & $\sqrt{ }$ & \\
\hline & $\begin{array}{l}\text { Position and configuration of the } \\
\text { building inside the site }\end{array}$ & & $\sqrt{ }$ \\
\hline $\begin{array}{l}\text { The building's } \\
\text { architectural expression as } \\
\text { observed from near the } \\
\text { entrance }\end{array}$ & $\begin{array}{l}\text { Properties of its outer spatial } \\
\text { enclosure }\end{array}$ & & \\
\hline \multirow{7}{*}{$\begin{array}{l}\text { The building's } \\
\text { architectural expression as } \\
\text { observed from inside the } \\
\text { building }\end{array}$} & Inner spatial enclosure & & \\
\hline & $\begin{array}{l}\text { Properties (color and materials) of } \\
\text { the walls and columns }\end{array}$ & $\sqrt{ }$ & \\
\hline & Composition of spatial enclosure & $\sqrt{ }$ & \\
\hline & Structural elements & & \\
\hline & $\begin{array}{l}\text { Properties (color and materials) of } \\
\text { the lamella construction }\end{array}$ & $\sqrt{ }$ & \\
\hline & $\begin{array}{l}\text { Composition (constructional system) } \\
\text { of the lamella }\end{array}$ & & $\sqrt{ }$ \\
\hline & Composition of spatial layout & & $\sqrt{ }$ \\
\hline
\end{tabular}




\section{CONCLUSION}

Based on the analysis results, it can be concluded that:

Firstly, the concept of Sundanese vernacular architecture is translated through the elaboration of the iconic shape of the roof which reminds of the shape of the roof in the Sundanese vernacular building. To accommodate its function as a multi-purpose hall, the designer adapted the form of space in the only public building in Sundanese villages, but elaborated the spatial layout into a rectangular shape. In order to create a flexible space, a wide-span construction is needed. Existing structure-construction uses modern technology, with local materials. Thus, it can be concluded that the application of the concept of vernacular architecture in the West Hall is to combine Sundanese architectural icons with the modern structure-construction system, while still using local materials. The research also concluded that it is not sufficient to apply the Sundanese concepts just for the ornaments. It is important to apply it in the dominant part of the building, such as in the shape of the roof.

Secondly, there are two kinds of design methods for applying vernacular concept to the design of contemporary architecture. The first is done with extensive studies to reveal the concepts that underlie all the activities and architectural forms of the Sundanese, then applying them in the design of contemporary architecture. The second is to empirically study all types of building forms in the Sundanese village, searching for the most iconic architectural forms, then elaborating and applying them to modern buildings that have similar functions. Pont's method in designing the West Hall was the later. While the first method requires designers to has certain level of academic prowess, the second proved to be more accessible and in most cases, more effective then the first one. The architectural work itself shall appeals more to the laypeople, as the iconic architectural form is more easily understood by them.

Thirdly, this research could be a source of inspiration to conduct further research, in order to discover Sundanese architectural icons. At the level of architectural practice, it also complements and at the same time improves the substance of the results of existing competitions regarding Sundanese architecture, by revealing how the concept of Sundanese vernacular architecture is elaborated and applied to buildings that accommodate modern functions. Thus, the persistence of the expression of Sundanese architecture shall remain and at the same time be able to accommodate new emerging modern functions.

Fourthly, the results of this research can be considered as an important input to conservation theories that glorify romantic restoration, which began since the Italian Renaissance and until now influences conservation guidelines in Asia, including in Indonesia. The methods of conservation should begin by carefully examining the potential scientific benefits that exist in buildings, so that conservation is not only based on building age (antiquity nostalgic) alone.

\section{REFERENCES}

Allahham, A. (2014). Traditionalism or Traditiona-Lieism: Authentication or Fabrication? International Journal of Architectural Research, 8(3), 64-73. https://doi.org/10.26687/archnetijar.v8i3.508

Arbi, E. (2017). Austronesian Vernacular Architecture and the Ise Shrine of Japan : Is There Any connection? Journal of Design and Built Environment, 3(1), 15-22.

Askari, A. H., \& Soltani, S. (2018). Contribution of building façades to attractive streetscapes: Study of two main streets in kuala lumpur city. Journal of Design and Built Environment, 18(1), 29-40. https://doi.org/10.22452/jdbe.vol18no1.4

Bloembergen, M., \& Eickhoff, M. (2020). The Politics of Heritage in Indonesia: A Cultural History (Asian Connections). Cambridge, England: Cambridge University Press.

Bonta, J. P. (1979). Architecture and its interpretation: A study of expressive systems in architecture (1st ed.). New York: Rizzoli International Publication Inc.

Chandra, R. (2012). Pengaruh Spirit Lokal pada Arsitektur Gedung Sate (Governement Bedrijven) dan Aula Barat ITB (Kompleks Technische Hoogeschool) di Bandung. Parahyangan Catholic University. Unpublished master thesis.

Dyck, J. Z. . van. (1922). Garoet en omstreken. Zwerftochten door de Preanger. Batavia: Kolff \& Company. 
Eldemery, I. M. (2009). Globalization challenges in architecture. Journal of Architectural and Planning Research, 26(4), 343-354. Retrieved from https://www.jstor.org/stable/43030883?seq $=1$

Falk, R. (2016) Power Shift. On the New Global Order. London: Zed Books

Harari, Y. N. (2014). Sapiens: A Brief History of Humankind. In The Guardian. London: Harvill Secker.

Jessup, H. I. (1975). Maclaine Pont's Architecture in Indonesia. London, England: University of London (Courtauld Institute of Art).

Kurniawan, K. R., \& Kusumawardhani, R. A. (2012). The influence of 19th century Dutch Colonial Orientalism in spreading Kubah (Islamic Dome) and Middle-Eastern architectural styles for mosques in Sumatra. Journal of Design and the Built Environment, 11(1), 1-13.

Kusno, A. (2000). Behind the postcolonial: Architecture, urban space and political cultures in Indonesia. In Architext (1st ed.). https://doi.org/10.4324/9781315011370

Lefaivre, L., \& Tzonis, A. (2011). Architecture of Regionalism in the Age of Globalization: Peaks and Valleys in the Flat World (1st ed.). England, UK: Routledge.

Mahatmanto. (2001). Ir. Henri Maclaine Pont: Representasi dalam Historiografi Arsitektur Kolonial di Indonesia. Bandung Institute of Technology. Unpublished master thesis.

Mahatmanto. (2002). Publikasi Pemikiran Henri Maclaine Pont Di Jawa. Dimensi, 30(2), 110-121. https://doi.org/10.9744/dimensi.30.2.

Malik, S., \& Hassan, K. A. K. (2019). An investigation of house designs in Lahore: Transformation of residential architecture from traditional to modern. Journal of Design and Built Environment, 19(1), 4959.

Michie, J. (2017) Advanced Introduction to Globalisation. Cheltenham: Edward Elgar

Passchier, C. (2007). Colonial Architecture in Indonesia References and Developments. In P. J. M. Nas (Ed.), The Past in the Present Architecture Indonesia (pp. 97112). Leiden: KITLV Press.

Rashid, M. (2015). Modernity in tradition: Reflections on buildingdesign and technology in the Asian vernacular. Frontiers of Architectural Research, 2015 (4), 46-55
Rodrik, D. (2011). The Globalization Paradox: Democracy and the Future of the World Economy. New York: W. W. Norton \& Company.

Rosidi, A. (2018). Manusia Sunda. Bandung: PT. Kiblat Buku Utama.(digital edition)

Rouhi, J. (2016). Development of the Theories of Cultural Heritage Conservation in Europe : A Survey of 19th And 20th Century Theories Development of the Theories of Cultural Heritage Conservation in Europe : A Survey of 19th And 20th Century Theories. 4th National and 2nd International Conference on Applied Research in Civil Engineering, Architecture and Urban Management, (4). Retrieved from https://en.civilica.com/Paper-ICSAU04ICSAU04_2354=Development-of-theTheories-of-Cultural-HeritageConservation-in-Europe-A-Survey-of-19thAnd-20th-Century-Theories.html

Salim, F. N. S. A. (2011). The Impact of Globalization on Architecture and Architectural Ethics. In The Impact of Globalization on Architecture and Architectural Ethics. https://doi.org/10.18848/978-1-86335-891$0 / \operatorname{cgp}$

Salura, P. (2013). The confusing language of building façades observed along Ciumbuleuit road in Bandung. Journal of Language and Literature. https://doi.org/10.7813/j1l.2013/4-2/14

Salura, P. (2018a). Misplaced eclecticism in the architecture of constitutional court building in Jakarta- Indonesia. Journal of Advanced Research in Dynamical and Control Systems, 10(02), 1553-1559. Retrieved from

http://repository.unpar.ac.id/bitstream/hand le/123456789/9096/artsc431_Purnama_Mi splaced Ecleticismp.pdf? sequence $=1 \&$ is Allowed $=y$

Salura, P. (2018b). The philosophy of architectural ordering principles. International Journal of Engineering and Technology(UAE), 7(2.9), 52-55.

Salura, P. (2018c). Sineger Tengah and Kacakaca as The Deep-Structure of Sundanese Architecture in Pasundan Land, West Java, Indonesia. International Journal of Engineering and Technology(UAE), 7(2.14), 314-317.

Salura, P., \& Clarissa, S. (2018). Interpreting Architectural Expression of House of 
Representative Building, Case study: East Java Provincial House of Representative Building in Surabaya, East Java, Indonesia. Journal of Advanced Research in Dynamical and Control Systems, (02Special Issue), 1543-1552. Retrieved from https://www.jardcs.org/backissues/abstract. php?archiveid $=4664$

Salura, P., \& Fauzy, B. (2013). Sintesis Elemen Arsitektur Lokal dengan Non lokal. Bandung.

Shahedi, B. (2012). Users Perceptions of Aesthetic Design Approach of Safavid Architecture, Iran. Journal of Design and Built Environment, 10(1), 114-117. Retrieved from https://ejournal.um.edu.my/index.php/jdbe/ article/view/5318/3111

Sholihah, A. B., Agustiananda, P. A., Junanah, \& Setiawan, W. (2019). Traditional architecture: The role of traditional festival in islamic historic district to achieve local community wellbeing. Journal of Design and Built Environment, 19(3), 13-23.

Soekiman, D., \& Purwanto, B. (2018). The Indis Style: The Transformation and Hybridization of Building Culture. Paramita: Historical Studies Journal, 28(2), 137-151.

https://doi.org/10.15294/paramita.v28i2.16 203

Sumalyo, Y. (1993). Arsitektur kolonial Belanda di Indonesia: mengetengahkan arsitek dan biro arsitek: Maclaine Pont, Thomas Karsten, C.P. Wolf Schoemaker, W. Lemei, C. Citroen. Ed. Cuypers \& Hulswit, Batavia Algemen Ingenieurs Architekten. Yogyakarta: Gadjah Mada Univ. Press.

Suratman, P. P. (2012). Membaca Elemen Arsitektur Signifikan pada Bangunan dalam Kaitannya dengan Konservasi Arsitektur, Kasus Studi: Gedung Aula Barat Institut Teknologi Bandung). Parahyangan Catholic University. Unpublished master thesis.

Suryono, A. (2015). Aspek Bentuk dan Fungsi dalam Pelestarian Arsitektur Bangunan Peninggalan Kolonial Belanda Era Politik di Kota Bandung. Parahyangan Catholic University. Unpublished doctoral thesis. 